\title{
The role of universities in innovation networks
}

The role of proximity on innovation dynamics in knowledge community precincts

\section{CHEPS WORKING PAPER 01/2017}

Milana Korotka. Department of Public Administration (University of Twente) m.korotka@utwente.nl

Paul Benneworth. CHEPS (University of Twente)

p.benneworth@utwente.nl

Tiago Ratinho. Merrick School of Business (University of Baltimore, the USA) tratinho@ubalt.edu

Series Editor Contact:

Nadine Zeeman, Katharina Lemmens-Krug \& Paul Benneworth

Centre for Higher Education Policy Studies

University of Twente

P.O. Box 217

7500 AE Enschede

The Netherlands

$\mathrm{T} \quad+3153-4893263$

$F \quad+3153-4340392$

E n.zeeman@utwente.nl

W www.utwente.nl/cheps 


\section{Table of Contents}

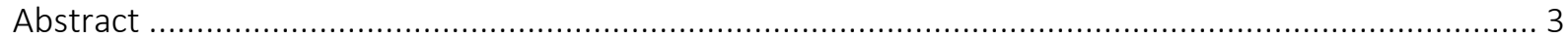

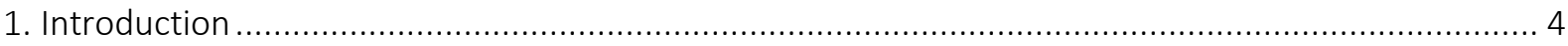

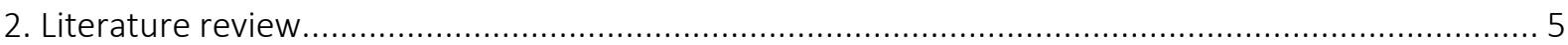

2.1 From Technopoles to Knowledge Community Precincts ............................................................ 5

2.2 Local KCP connections boosting external network strengths ................................................... 7

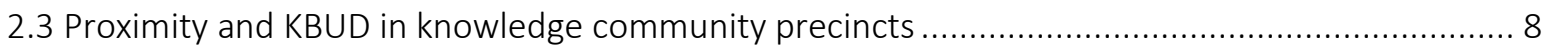

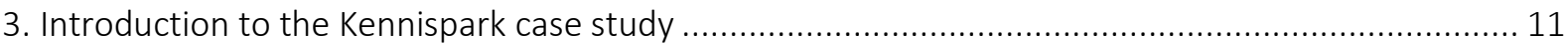

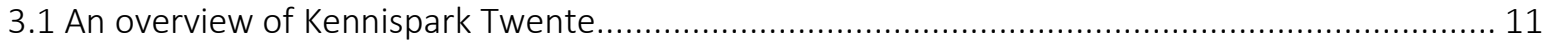

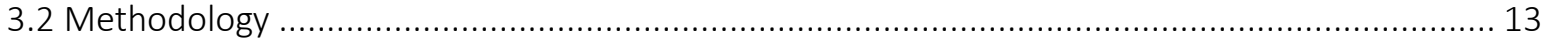

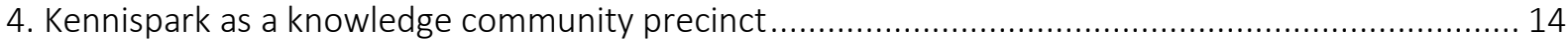

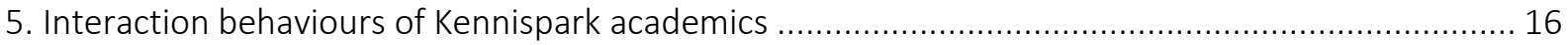

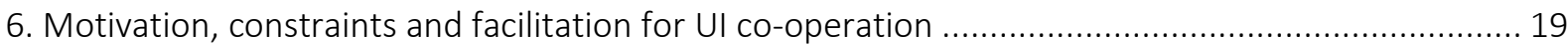

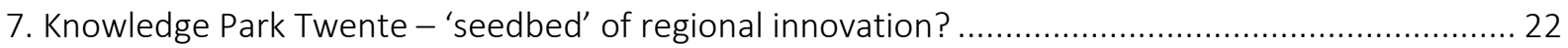

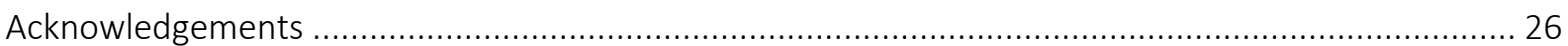

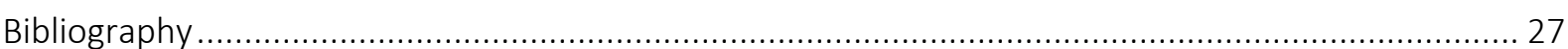




\begin{abstract}
This paper critically analyses the recent fad for using technopoles and as key economic growth drivers stimulating innovation dynamics in particular territories. Conceptualising technopoles as "knowledge community precincts" creating science-park style benefits, we characterise these benefits as creating proximity between participants. Studying a typical science city, Kennispark in Eastern Netherlands, we discover that geographical proximity is much less important than social, cognitive or institutional proximity to Kennispark academics. The paper argues that local dimension to technopoles requires further analysis, and policy should focus on embedding local firms more actively in technopoles' knowledge communities.
\end{abstract}

Key words: university third mission, knowledge exchange, proximity \& cognateness, knowledge-based urban development, communities of practice 


\section{Introduction}

Charles \& Wray (2010) argued that the rise of science cities since 2000 could only be understood as a reframing of Castells \& Hall's (1994) notion of technopoles in a ways that made both digestible to and usable by policy makers. This has provided the basis for a huge expansion of both academic and policy interest in the idea of investing in science facilities as an integral part of urban development policy (Perry \& May, 2011; Benneworth et al., 2011). Nowhere is this illustrated better than the OECD (2011) who identified the ingredients that contribute to the recipe for a successful "science city", and highlighted the different national contexts within which science cities are currently being developed (Anttiroiko, 2004). But this framing of science cities provides a stark reminder of the limits of the policy applications of these models. We have already experienced two waves of "policy bubble" in neo-endogenous models, namely the 1980s enthusiasm for science parks and the 1990s enthusiasm for clusters (Quintas et al., 1992; Martin \& Sunley, 2003).

Of course the lessons of these episodes are not that these original ideas or analyses were in some way flawed. Rather, academically valid notions became caught up in a consensus on driven by a quasi-concept or policy-concept into which substantial numbers of stakeholders could agree (cf. Bøås \& McNeill, 2004; Böhme \& Gløersen, 2011). Thispaper seeks to place an urban science in the context of the latest wave of potentially "irrational exuberance" in models of knowledge based urban development, highlighted by Perry \& May (2010):

"a dominant consensus [which] has emerged around the need to increase the inter -relationships between universities and their localities for the mutual benefit of all involved ... cities and city-regions are adopting a number of strategies and policies designed to build science cities, knowledge capitals, silicon alleys or technology corridors" (p. 6).

This paper contributes to debates around technopoles and science cities by focusing on the processes of knowledge-based development which these new kinds of urban space create. We draw on Yigitcanlar's (2008) notion of Knowledge Community Precincts (KCPs) as a way of understanding how science cities function, hosting social learning 
communities focused around solving innovation problems that build up unique useful knowledges with external value. A key claimed mechanism by which KCPs operate is through encouraging proximity and thereby facilitating tacit knowledge exchange. However, we note that KCP models assume that participants have a reason to collaborate, and using an emerging body of science policy literature, we question whether proximity is a sufficient reason for academics to collaborate.

Our overall research question is how can KCPs and their underlying shared knowledge resources contribute to participating academics' needs to be excellent in wider academic/ scholarly networks. To answer this question, we explore the extent to which one such KCP project, Kennispark, in the East of the Netherlands, functions as a 'science park at regional scale' Kennispark, both in terms of creating an active knowledge community, but also the motivations and attitudes of participating academics towards the value of local collaboration activities. On this basis we are able to provide a degree of realism to the limits to science city concepts and policies, contributing to a wider debate regarding the role of science and 21 st century industrial complexes.

\section{Literature review}

\subsection{From Technopoles to Knowledge Community Precincts}

The publication of Technopoles of the World (Castells \& Halls, 1994) sparked a huge interest in the use of high-technology industrial complexes as a means of driving innovation-based economic development. The book emerged at the same time as a realisation within the economic community of the increasing importance of knowledge capital as drivers of productivity growth and economic development (Romer, 1994; Solow, 1994; Temple, 1998). In an era where knowledge based development was becoming increasingly important, cities functioned as critical loci of knowledge based development, facilitating interaction and knowledge exchange between innovators, and hence driving knowledge accumulation (Knight, 1995). Knowledge was a source of competitive advantage for cities, and any firm seeking to access a relatively distinct piece of knowledge was required to engage in some way with the host territory (Gertler, 1995). 
But the question still arose of how to turn this explanation of why particular cities those already endowed with successful high-technology clusters - were successful into a more generalised concept of economic change, or indeed to develop meaningful policy recommendations from it. The visible success of Silicon Valley in particular spawned a rash of attempts by policy-makers to duplicate its successes, leading to what Hospers (2006) referred to as the rise of "Silicon Somewheres", pale imitations of "the original industrial core of the revolution in information technology"(Castells \& Hall, 1994, p. 12). Somewhere between the problematic notion of the ubiquitous Technopole and the continued growth and transformation of the knowledge economy was a realisation that the nature of economic production was changing in ways that had a distinctly urban dimension (Charles \& Wray, 2010).

A key feature of knowledge capital - in contrast to traditional capitals of land, labour and machinery - was a notion of 'increasing returns' i.e. that knowledge capital benefited from agglomeration and proximity to other forms of capital (Gordon \& McCann, 2005). The reason for this was that not all forms of knowledge were easily transferred over space, and some kinds of knowledge, referred to tacit knowledge, know-how, knowingin action were best transferred in personal contacts through social learning processes (Nonaka \& Takeuchi, 1995; Garud, 1997; Amin \& Roberts, 2008). There has been an increasing emphasis on how cities facilitate these kinds of knowledge spillovers and facilitate the kinds of social interactions that encourage knowledge combination and creation, that ultimately support innovative potential and urban competitiveness.

Analysis of knowledge-based urban development have therefore sought to explicate the precise processes by which knowledge-based urban agglomerations can facilitate economic growth (Yigitcanlar \& Velibeyoglu, 2008; Perry \& May, 2010). Yigitcanlar (2010) advanced the notion of a knowledge-community precinct as an explanation for precisely how these benefits can be produced, a knowledge community precinct (KCPs). A KCP brings together different knowledge actors who interact around specific innovation projects, and through their social learning and interaction, create specific kinds of knowledge embedded within these learning communities (Amin \& Roberts, 2008; Gertner et al., 2011). These locally-specific knowledge pools in turn makes these KCPs 'places to be' for those seeking to access those particular economically valuable knowledges that are produced in the course of intense interaction between KCP 
residents (Perry \& May, 2010). This binding of external actors to the knowledges in these precincts can function to increase the relative strength of these host cities in global city networks (cf. Smith, 2003; Yeung, 2009).

\subsection{Local KCP connections boosting external network strengths}

Benneworth et al. (2011) refer to the proliferation of policy interventions seeking to promote KCP benefits in particular city-regional territories as urban science (following Anttioiko, 2004; Perry and May, 2010 and Perry \& May 2011). Studies of urban science following this definition have focused on the physical developments which are emblematical of the kinds of projects by which policy-makers have sought to replicate KBUD benefits in their territories (Benneworth et al., 2009). KCPs have some commonalities with incubators, providing the three dimensions that define a successful business incubator - infrastructure, business support and access to networks (Ratinho, 2011), albeit at a larger scale. KCPs may have both passive and active elements, creating the opportunities passively for actors to interact as well as actively undertaking interventions to simulate interaction between participants (Benneworth \& Ratinho, 2014a). In particular, these active elements have become particularly important in cities where there are not already strong existing networks and clusters of innovators, as part of a process of constructing regional advantage or smart specialisation strategy (Asheim et al., 2011; McCann \& Ortega-Argiles, 2013).

If one considers a Knowledge Community Precinct as a science park extended to the urban-scale (cf. Anttiroiko, 2004), incorporating not just activities of firms, universities and government actors but encompassing them, then KCPs active elements are those that integrate between these various participants. Good insights into these active elements have been derived from a close reading of literatures on innovation and hightechnology entrepreneurship, which provide insights into why innovating firms do not always spontaneously choose to work with those with the knowledge resources able to help them. Miller (2014) argues that there are three kinds of active benefits which can be constructed in urban science settings, namely creating linkages and networks, providing complementary services to accelerate innovation and supporting technologies with long lead-times. Likewise, Ratinho \& Henriques (2010) argue that urban science parks bring together relevant innovation actors in ways that can stimulate the intense 
interactions necessary for effective innovation-led growth alongside effective management that provides suitable support services for high-technology entrepreneurs.

What these interventions all seek to do is construct opportunities for interaction between actors within KCPs, and therefor to create locally-embedded specific knowledges for which there is substantial demand from outside users, thereby anchoring those external interests into these local places. We contend that there are three kinds of intervention which might potentially support these interactions. Firstly, they offer infrastructure for co-location, physically creating a single location where various actors come together and have the opportunity to undertake shared activities, through joint ventures, shared equipment, Living Labs, and co-creatories. Secondly, they may seek to mobilise knowledge communities within these precincts, running activities from informal network meetings to formal cluster groupings that bring people with similar interests and knowledge together in the hope of mobilising interaction between them. Thirdly, they provide services that are necessary for to exploit the opportunities that emerge when co-located interacting actors see opportunities for novel innovative activities: these activities may involve facilitating technology entrepreneurship, providing business development advice, signposting actors to those that may be able to help them, or running various kinds of funding competition for innovative and creative ideas.

\subsection{Proximity and KBUD in knowledge community precincts}

But at the same time, there seems to be a presumption that physical co-location is sufficient to increase innovative outcomes, as a precondition for tacit knowledge exchange and developing unique knowledge pools or competences. There has been a shift in the nature of the knowledge economy given the increasing importance of virtual interactive technologies which facilitate geographically extended learning communities, what Benneworth \& Ratinho (2014b) refer to as the social knowledge economy. This means that it is not just geographical proximity (co-location) which may be germane for interaction but also other forms of proximity which create preconditions for interaction, that Boschma (2005) stylises as organisational, institutional, cognitive and social.

But proximity is a facilitating rather than an initiating factor - although actors may be proximate, actors may choose to achieve their desired innovative ends through other means, either not innovating or innovating with other kinds of actor. Broekel \& Boschma 
(2012) highlight what they call the 'proximity paradox' where innovative actors choose to interact with remote actors because of social preferences and capital that make those interactions far more productive than those with local actors. Conversely Caniëls et al. (2014) posit the existence of a personal dimension to proximity - the idea of a 'click' between two people - that cannot be explained in terms of the embedding of people (organisations, epistemic communities, cultures) in various contexts but is specific to the people and personalities involved. And finally is the importance of a material basis for collaboration, the underlying innovation projects or activities from which both participants benefit from the creation of a shared knowledge pool (Gertner et al., 2011).

It is this last point that we would like to raise in the course of this paper, and in particular to question the assumption that academic scientists automatically have interest in the knowledge being generated within particular KCPs. Although some KCPs have an open innovation ethos bringing together different firms in similar fields with collaboration potential, more typically they attempt to create knowledge concentrations incorporating upstream (academic) and downstream(commercial) knowledge potentially linked through intermediary knowledge exchange organisations. Whilst the regional development literature might have mobilised a heuristic of knowledge creators and knowledge exploiters working harmoniously within regional contexts to create globally-valuable knowledge (cf. Cooke, 2005), this ignores the divergent interests that these communities have in shared knowledge creation. Indeed, without a fundamental basis for co-operation, then there will not be the social interactive activities that lead to the creation of collective knowledge resources and ultimately the KBUD effects.

We therefore argue that more attention needs to be paid to the basis for co-operation between KCPs and in particular whether interactions are sufficient to create shared knowledge resources that might be attractive and valuable to those immediately outside the KCP (creating network effects anchoring powerful external partners within local networks, Yeung, 2009). We in particular seek to problematize the notion that academics will automatically choose to work with local innovative actors simply because of proximity effects. More work remains to be done on understanding academics' precise motivations for engaging with non-academic partners and in particular industry (d'Este \& Perkmann, 2011). But at the same time, academic engagement seems to involve balancing between the potential negative effects on the universality of the 
research against the positive effects that engagement might bring in terms of access to resources, knowledge and expertise externally (Baldini et al., 2007; Lam, 2010).

In thispaper, we therefore focus specifically on academics motivations for engaging with local actors, and ask the research question "why do academics choose to engage with non-academic research partners within KCPs"? Our starting point is that academics are involved in knowledge creation activities which they valorise in their own networks on the basis of their research excellence (Benneworth \& Charles, 2005). In choosing to work with local firms in a KCP, proximity must provide a competitive advantage in these wider academic networks within which research excellence is judged. Effective KCPs will therefore be those that are best able to help participating academics meet their own research needs, and therefore we ask the following three operational research questions:

- What do the KCPs' academics seek to derive from business engagement with external partners?

- What types or proximity influence academics' choice to cooperate with local/distant firms?

- How can KCPs build 'useful proximity' in this context?

To address this question, we focus on one particular KCP, the case of Kennispark in the east of the Netherlands, where regional actors including university, the public sector and firms have invested in trying to create a single knowledge district for the Twente region. We firstly examine the nature of the KCP on the basis of documentary analysis, mapping the efforts that have been placed into building infrastructures, community networks and support for new innovative activities within the Kennispark activity. We then examine on the basis of a survey of academics from the participating university, the University of Twente, their engagement behaviours and their underlying rationale. That in turn provides the basis to reflect on the overarching question posed in the introduction to this paper, namely how can KCPs and their underlying shared knowledge resources contribute to participating academics' needs to be excellent in wider academic/ scholarly networks. 


\section{Introduction to the Kennispark case study}

\subsection{An overview of Kennispark Twente}

The Knowledge park (Kennispark) situated in Twente region (see Map 1), the Netherlands is a business incubator and urban science project underpinned by a strong entrepreneurial vision and beneficial location. The University of Twente (UT) has an integrated entrepreneurial culture, diversified funding base, tight relationships with internal organisations and produces excellent quality of applied research (Lazzaretti \& Tavoletti, 2007). UT consistently ranks amongst the most entrepreneurial universities in the Netherlands and Europe, with more than 700 firms emerging from the university in the last 20 years. In 2013, Elsevier magazine (a Dutch language analogue of the Economist) declared UT the "most entrepreneurial university" in its national valorisation ranking of Dutch Universities).

\section{Map 1 The position of the Twente region in Europe}

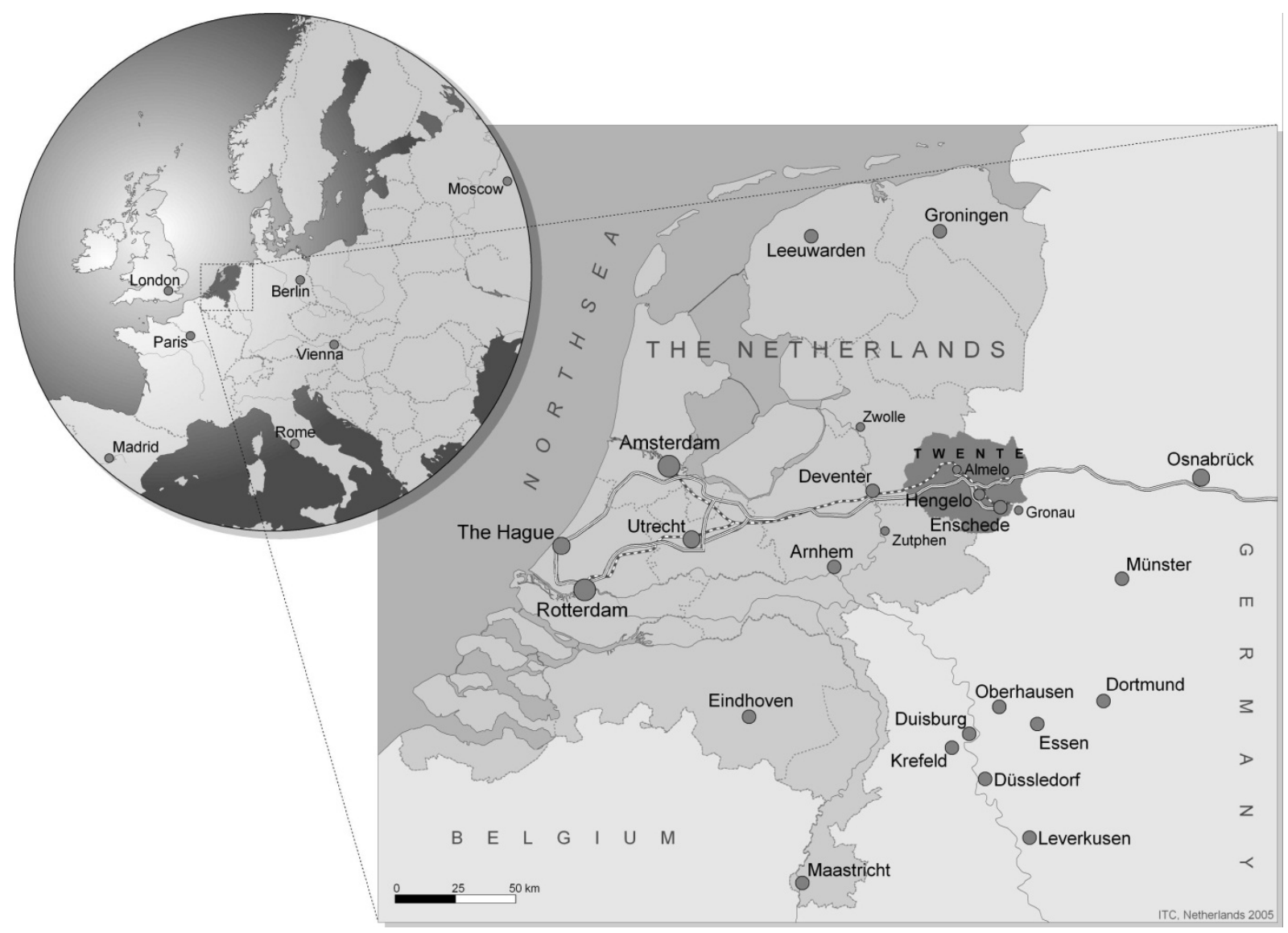

Source: ITC, University of Twente, Enschede (permission required). 
But this situation has not arisen in a vacuum: UT is relatively young and innovative university in an old industrial region Founded in 1961, UT's main regional mission was to support the survival of the textiles industry and its diversification by increasing the number of highly trained engineers (Schutte, 1999). However, from the 1970s, UT suffered as the textiles industry declined, leading to calls to close the university, and UT reinvented itself as a source of new industries, developing strong leadership and support structures to promote entrepreneurship (Clark, 1998). Today, the university has 10,000 students and 3,300 staff in social and technical sciences, with a research focus in five areas (each with a corresponding research centre, listed in brackets): nanotechnology (MESA+), telematics and information technology (CTIT), biomedical technology and technical medicine (MIRA), innovation and governance studies (IGS) and Geo-information science and earth observation (ITC).

The university is actively engaged with both regional industry but also regional policymakers and business support organisations, including the municipality, the Chamber of Commerce, the regional development agency, the province, the region and national actors. The university has actively engaged with regional intermediaries since the 1970s (with the creation of the Provincial Regional Development Agency), actively participating in the creation of a Business and Technology Centre to the south of its campus, the development of land adjacent to the BTC and university into a Business and Science Park, and more latterly, the integration of the BSP and University Campus into a single knowledge space, the so-called "Kennispark" (Knowledge Park, see box 1 below). 
Box 1. The Knowledge Park Twente (Kennispark)

- The largest science park in the Netherlands with over 380 companies

- Joint initiative of the Province Overijssel, the City of Enschede, the University of Twente and the Saxion University of Applied Sciences.

- Each year 60-70 new start-ups from Saxion University of Applied Sciences and the University of Twente

- University of Twente proclaimed most entrepreneurial university of the Netherlands by Elsevier Magazine and Scienceworks (2013)

- Provides support to entrepreneurs - coaching, financing, legal advisory service

- Extensive innovative network

- Innovative facilities:

- high-tech laboratories;

- open innovation centre opened innovation centre for 400 to

knowledge intensive companies, open innovation service and their service providers.

- PR office for branding and promotion of start-ups

\subsection{Methodology}

This paper reports fieldwork research undertaken under the aegis of and elsewhere reported as Korotka (2012), extended in the course of 2013-14 with additional desk research. The study was exploratory to explore the mechanisms underpinning the development of localised knowledge pools as a reason for KCP formation. The UT was chosen because of its history in development the Kennispark activity with roots going back 30 years. The first fieldwork element involved a review of documents exploring the creation of the KCP in terms of the infrastructure, the networks and the business support developed in Kennispark. This was complemented with a survey exploring how and why academics choose to collaborate with business partners, and the circumstances under which local/ regional partners might be chosen over national/ regional partners. A survey was undertaken of academic researchers from the UT's five research institutes (MESA+, MIRA, CTIT, ITC, and IGS)Researchers were asked whether the proximity makes a difference and does it influence them. The survey aimed to provide in-depth 
understanding of researchers' attitudes towards cooperation with external partners and factors influencing their willingness to develop detailed micro-level connections with entrepreneurs and policy-makers.

The survey questionnaire aimed to foreground the role of proximity in scientific/commercial interactions, exploring the circumstances under which local/regional partners might be chosen over national/ regional partners. The questionnaire consisted of 7 screens, including an invitation message introducing the study and 14 questions, as well as demographic questions regarding age, gender, research position and research experience, thereby providing the opportunity to crosstabulate the answers in analysis as well as comparing how opinions vary between subgroups. As the questionnaire was focused on the researchers' attitudes towards partnership with external partners, it also included questions regarding the primary location of those external partners, their primary form of contact, frequency of cooperation, rationales and barriers for effective partnership, and facilitators for the cooperation. Closed-ended questions were chosen as questions format with multiplechoice option for the answers with a five points Likert scale for the ranking type answers. To ensure that the researcher was actively involved in university cooperation (i.e. had knowledge of the field), this factor was a screening choice in the first question, and those who had not collaborated with industry were thanked for their interest and the survey closed to them. In total 1144 academics from five research institutes of Kennispark were asked to specify if they are engaging in the joint activities with industry. A total of 199 academics replied, with 62 saying that they indeed had contacts with external partners.

\section{Kennispark as a knowledge community precinct}

Kennispark has been hailed by the Kerngroep Innovatie as the most important engine of the Dutch knowledge economy (Kerngroep Innovatie, 2012), perhaps slightly hyperbolic when one considers the strengths of the Eindhoven Brainport complex (see Carvalho \& Van Winden, 2015). Nevertheless, a series of important policy and analytic reports in the Netherlands (including a national economic development strategy, the national spatial strategy, a cluster analysis, and a cluster observatory) have highlighted that there is something distinctive about the environment provided around Kennispark for the 
transformation of technology into new businesses. In a sense, Kennispark is a very special kind of high-technology business incubator unit, one that operates not at the level of a single building, but at the level of the Knowledge Precinct, an integrated technology campus covering around 6,000 employees. In this section we therefore explore the extent to which the Kennispark project provides each of the three dimensions by which Ratinho (2011) characterises incubators, business support, networks and infrastructure.

Firstly, in terms of business support, Kennispark has developed a complex set of support for new and growing business, targeting the different elements and stages of business growth. A key element of this is the support for starting entrepreneurs, continuing the work begun by the Temporary Entrepreneur Position (the TOP programme, which produces around 400 companies in 25 years), providing business advice, a temporary loan, a physical location and contact with a university research group for potential hightechnology starters. Another key element of the business support are the various financial support streams that are co-ordinated through Kennispark, including the Twente Technology Fund, the Innovation Fund Enschede and financing from the regional venture capital (VC) firm, PPM Oost. A range of supports and subsidies are available for growing technology businesses to accelerate their innovative activities and support the development of innovative clusters (Kerngroep Innovatie, 2012).

Secondly, Kennispark represents a relatively dense innovation ecosystem built up from a wide degree of overlapping networks. The heart of the TOP model by which firms are created is that firms drawing from different kinds of social capital embedded within networks, whether that is business advice, scientific knowledge, business mentoring and help in building businesses. Over time, a number of these firms have grown and become highly successful, and have placing their own resources at the access of new companies, whether creating new spin-offs themselves, or providing business advice for new startups, or indeed creating markets for start-ups by buying in the services they offer. A number of high-technology companies in the region including spin-offs formed the Twente Technology Circle (TKT) that helps starting and growing companies to access the resources - particularly advice and contacts - they need to stimulate high technology innovation-based growth. Kennispark seeks to function as a 'network of networks' hosting and connecting up the various networks that already exist in the 
region and make them more transparent and visible so starting and growing entrepreneurs may maximise the benefits they receive.

Finally in terms of infrastructure, Kennispark acts as a central focus and meeting point for regional high technology industry, with around 2/3 of firms active in R\&D in the region located partly or wholly in the Kennispark area. Kennispark has been created as a single integrated space bringing together the formerly adjacent but separate university campus and Business and Science Park to create a single integrated space of around 150ha. The university facilities have been physically replanned (the entire campus has been rebuilt since 1998) to open it up to business around a central "Education and Research Square", the south side of which is the Gallery building. Formerly lecture theatres of the university, it has been redeveloped as an innovation centre for knowledge intensive companies actively engaged in open innovation with connections to the university. The site is overseen by the Kennispark Twente Foundation, a joint initiative of the Province of Overijssel, the City of Enschede, the University of Twente and the Saxion University of Applied Sciences.

Despite the relatively rosy picture presented by the narrative as well as the awards and plaudits that Kennispark has received for its work in knowledge exchange, there remain some barriers to effective collaboration between universities and external partners. Freitas and Verspagen (2009) argue that despite the physical co-location of all these activity, there are in fact only relatively sporadic interventions and weak engagement of channels between universities and their users. Benneworth and Hospers (2007) draw out the problem of a lack of analytical literature related to UT's entrepreneurial activity beyond a neat story of regional reinvention, with a clear empirical gap in tracing how particular activities within a KCP have consequences at the level of the region.

\section{Interaction behaviours of Kennispark academics}

The following two sections seek to provide an empirical basis to explore the regional consquences of Kennispark as a KCP by exploring how important physical proximity was to participants. This reports on the basis of the 62 academics who indicated they were actively involved in external co-operation in various ways, from collaborative research, problem solving activities, student placement activities to creating spin-off companies, working with start-ups and informal networking activities. The most popular kind of 
association with external parties came through collaborative research (32\%), with $25 \%$ taking part in problem solving activities. Over 20\% were involved with informal networking activities, and 19\% in student placement activities. A very small portion of the sample was concerned with working with start-ups and creating spin-off companies - 11\% and 3\% respectively (see Figure 1 below). For those academics involved in external engagement, collaborative research and problem-solving (i.e. intensive knowledge exchange activities) were the most frequent kinds of interaction.

\section{Figure 1 Types of activities (\% of respondents)}

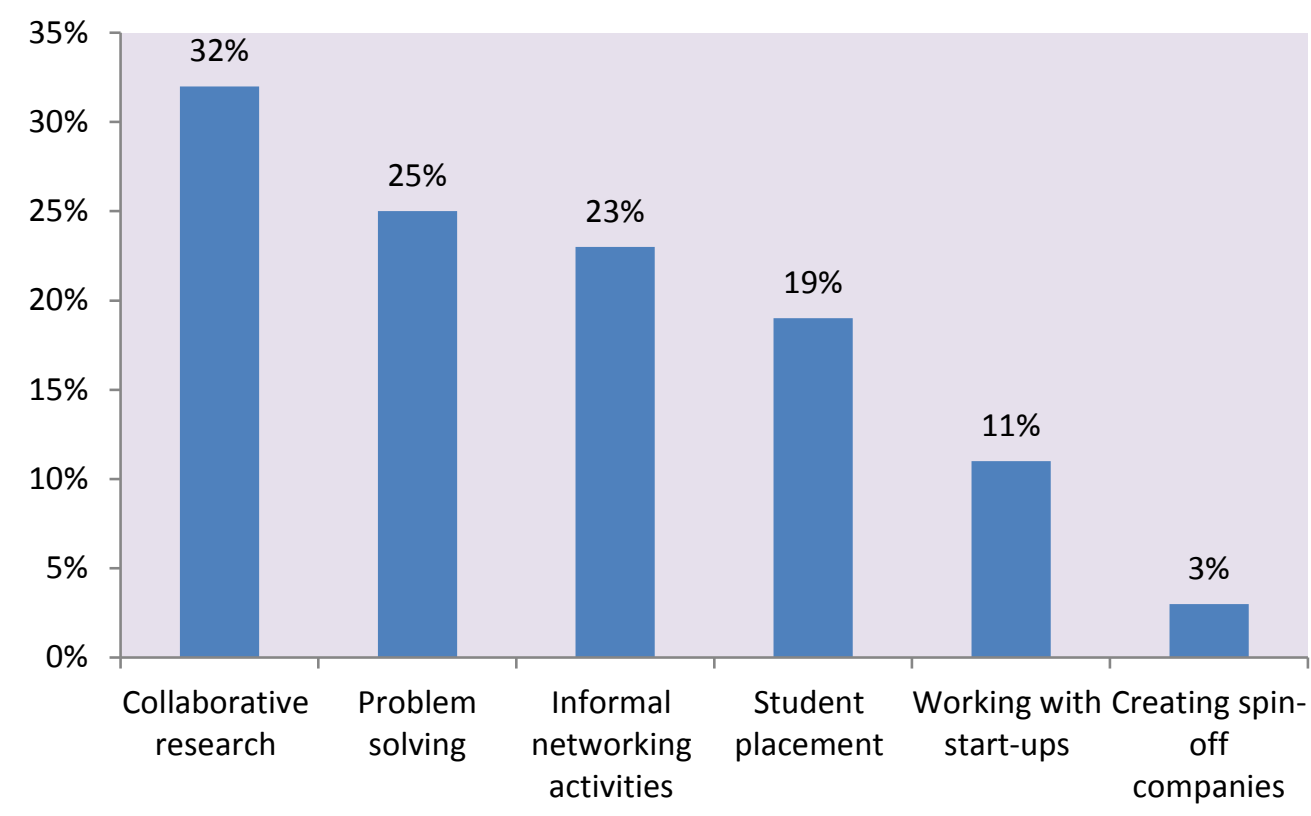

Secondly, despite the knowledge-intensity of the main kinds of interaction, the primary location of external partners of the academics is national (53\%) and with the least active collaboration happens on the local KCP level (Figure 2). 
Figure 2 The location of external partners (\% of respondents)

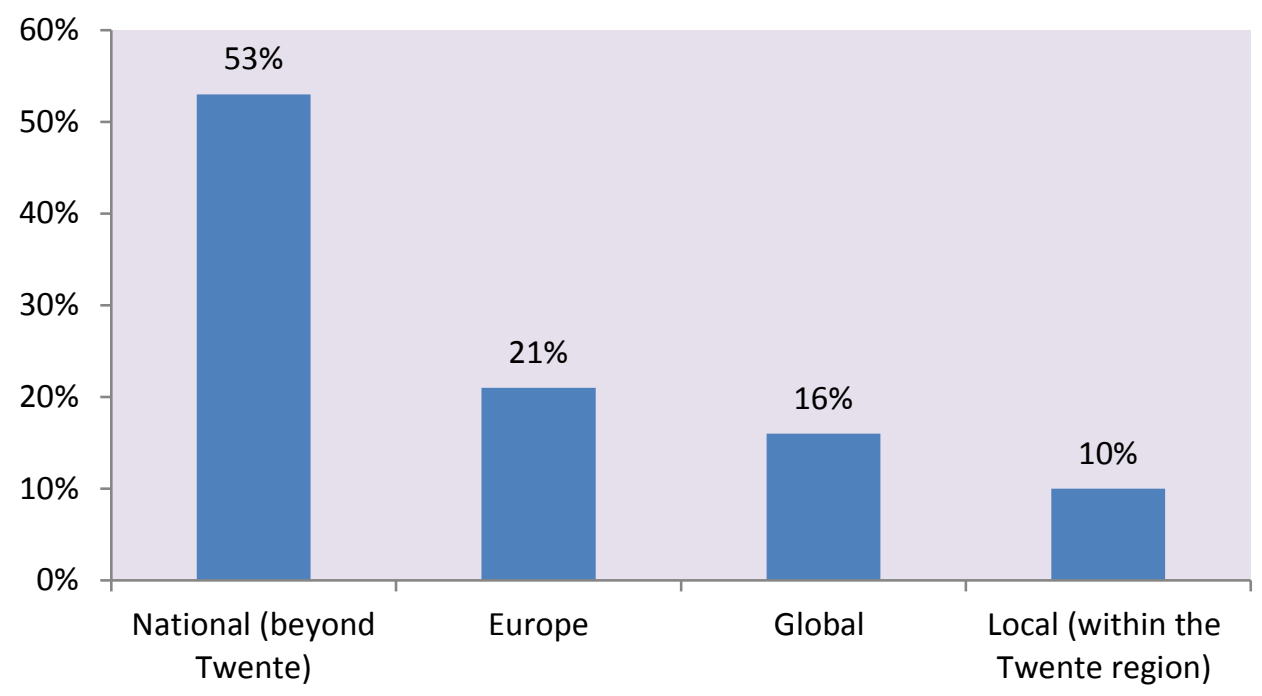

However, despite the relatively limited importance of local co-operation, modes of communications between academics and their partners suggested that social modes of interaction were important, suggesting in turn that academics were exchanging social knowledge with their partners. Around $60 \%$ of the academics surveyed reported a preference for face-to-face meetings with their external partners, whilst the lowest number of researchers used telephone/ skype/ Instant messaging (6\%) as a primary form of contract with their external partners (Figure 3).

Figure 3 Primary form of contract (\% of respondents)

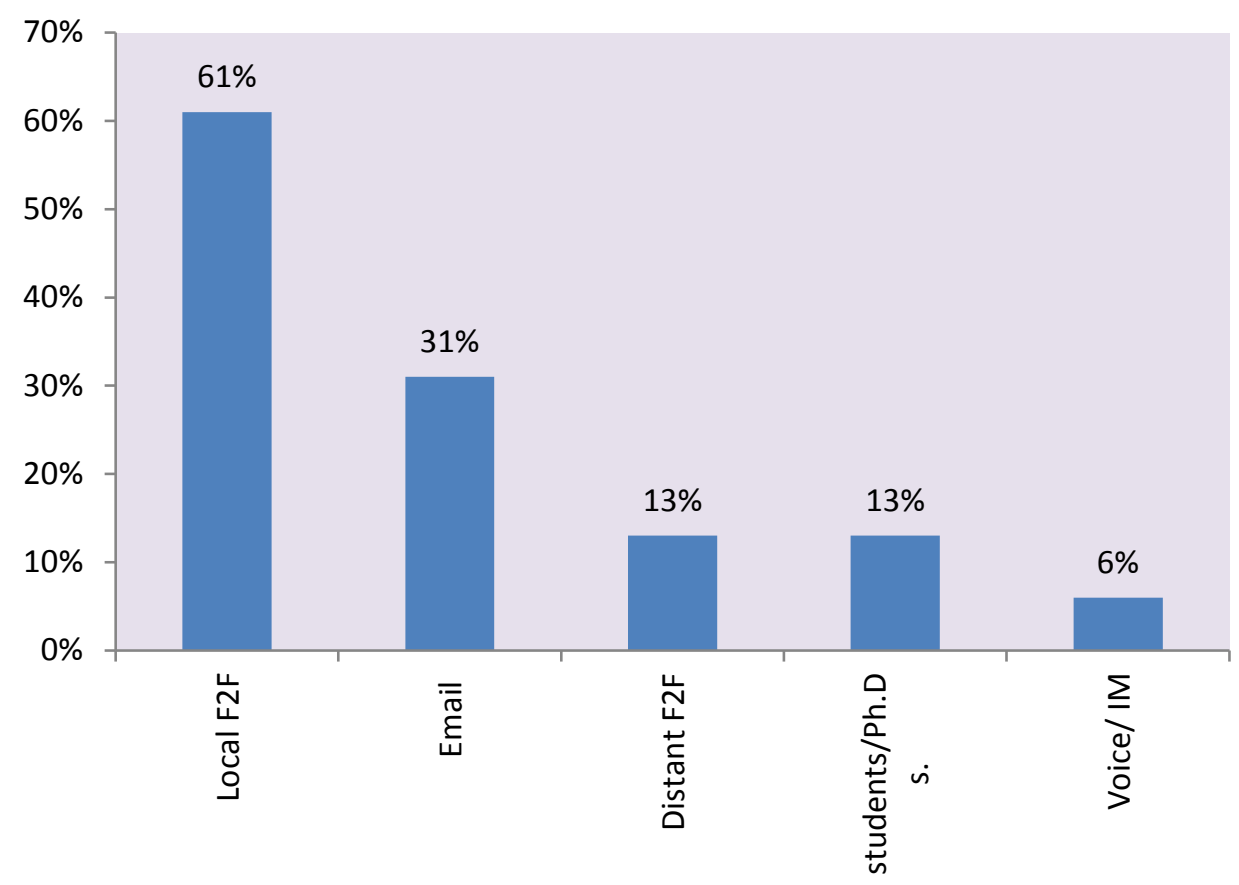




\section{Motivation, constraints and facilitation for UI co-operation}

To make sense of those findings, which present a slightly confusing picture that despite not favouring working with local partners, academics working with external partners are involved in knowledge intensive activities (joint research and problem solving) based on social knowledge exchange approaches, we now turn our attention to why they interact with external partners. Respondents were given a choice of seven reasons for why they interacted with external partners (shown in figure 4) with the pattern of answering suggesting three kinds of reasons for working with external partners. The most common set of responses related to the practicalities of carrying out research, namely developing future research opportunities (73\% agree, 15\% strongly agree) and maintaining useful contacts (60\% agree; $27 \%$ strongly agree). The next set of motivations were to increase their research's impacts, whether seeing their research outcomes implemented in innovative technologies (56\% agree, 19\% strongly agree) or out of a sense of responsibility to contribute to social and economic development (55\% agree, $19 \%$ strongly agree). The least common set of reasons related to undertaking excellent research, whether supporting world-class research (52\% agree, 13\% strongly agree), developing an international research career (39\% agree, 5\% strongly agree), or accessing public research grants (37\% agree,15\% strongly agree)

\section{Figure 4 Motivation for activities with external partners (mean score, \%)}

$\begin{array}{lllllll}2 & 1 & 3 & 4 & 5 & 7 & 6\end{array}$




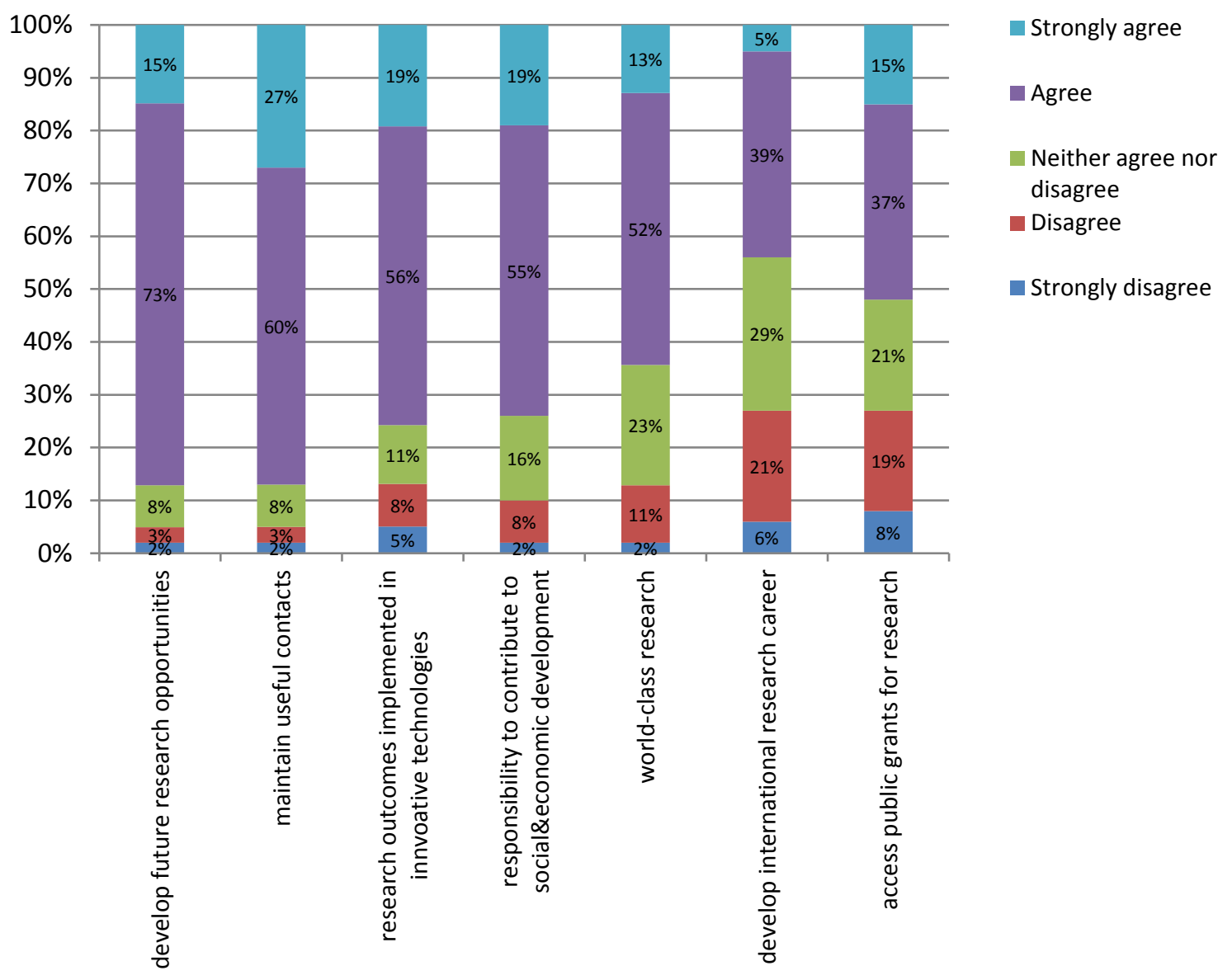

In terms of which kinds of proximity were important to academics collaborating externally, we coded five dimensions of proximity (cognitive, organizational, social, institutional and geographical, following Boschma, 2005) in sentences describing the conditions, under which academics agree/disagree to cooperate with external partners. For negatively phrased statements (marked with an asterisk in Table 1), we reversed the rating, so that higher was always negative (disagree). Ratings on proximity were mostly positive, what proves the importance for academics of each dimension of proximity. The negative statements showed that the most important factors for researchers are to have independence in research and maintain flexibility of interaction. Geographical proximity is important for academics, but not in the sense of acquiring high-quality research grants. 


\section{Table 1. Role of proximity in UI cooperation (crosstab)}

\begin{tabular}{|c|c|c|c|c|c|c|}
\hline \multirow{3}{*}{$\begin{array}{c}\text { Type of } \\
\text { proximity }\end{array}$} & \multirow{3}{*}{$\begin{array}{l}\text { Question } \\
\text { Considering your most important } \\
\text { activities with industrial partners. }\end{array}$} & \multicolumn{5}{|c|}{ Answer } \\
\hline & & $\begin{array}{l}\text { Strongl } \\
\mathrm{y} \\
\text { disagre } \\
\mathrm{e}\end{array}$ & $\begin{array}{c}\text { Disagre } \\
\mathrm{e}\end{array}$ & $\begin{array}{l}\text { Neither } \\
\text { agree nor } \\
\text { disagree }\end{array}$ & Agree & $\begin{array}{l}\text { Strongl } \\
\text { y agree }\end{array}$ \\
\hline & & $\begin{array}{c}\text { Count } \\
\%\end{array}$ & $\begin{array}{c}\text { Count } \\
\% \\
\end{array}$ & $\begin{array}{c}\text { Count } \\
\% \\
\end{array}$ & $\begin{array}{c}\text { Count } \\
\%\end{array}$ & $\begin{array}{c}\text { Count } \\
\% \\
\end{array}$ \\
\hline \multirow[t]{2}{*}{ cognitive } & $\begin{array}{l}\text {...frequent communication with } \\
\text { industrial partners helps to conduct } \\
\text { innovative projects more effectively }\end{array}$ & $\begin{array}{c}1 \\
2 \%\end{array}$ & $\begin{array}{c}6 \\
10 \%\end{array}$ & $\begin{array}{c}17 \\
27 \%\end{array}$ & $\begin{array}{c}35 \\
56 \%\end{array}$ & $\begin{array}{c}3 \\
5 \%\end{array}$ \\
\hline & $\begin{array}{l}\text {...more frequent interaction with } \\
\text { companies allows to conduct research } \\
\text { independently. }\end{array}$ & $\begin{array}{c}2 \\
3 \%\end{array}$ & $\begin{array}{c}20 \\
32 \%\end{array}$ & $\begin{array}{c}27 \\
44 \%\end{array}$ & $\begin{array}{c}10 \\
16 \%\end{array}$ & $\begin{array}{c}3 \\
5 \%\end{array}$ \\
\hline \multirow[t]{2}{*}{ organizational } & $\begin{array}{l}\text {...informal networks with firms help } \\
\text { to control innovative projects more } \\
\text { effectively. }\end{array}$ & $\begin{array}{c}2 \\
3 \%\end{array}$ & $\begin{array}{c}9 \\
15 \%\end{array}$ & $\begin{array}{c}22 \\
35 \%\end{array}$ & $\begin{array}{c}27 \\
44 \%\end{array}$ & $\begin{array}{c}2 \\
3 \%\end{array}$ \\
\hline & $\begin{array}{l}\text {...communication with firms through } \\
\text { informal networks gives more } \\
\text { flexibility in research. }\end{array}$ & $\begin{array}{c}3 \\
5 \%\end{array}$ & $\begin{array}{c}10 \\
16 \%\end{array}$ & $\begin{array}{c}19 \\
31 \%\end{array}$ & $\begin{array}{c}26 \\
42 \%\end{array}$ & $\begin{array}{c}4 \\
6 \%\end{array}$ \\
\hline \multirow[t]{2}{*}{ social } & $\begin{array}{l}\text {...working with industrial partners I } \\
\text { trust helps me to raise the } \\
\text { effectiveness of innovative projects. }\end{array}$ & $\begin{array}{c}1 \\
2 \%\end{array}$ & $\begin{array}{c}4 \\
6 \%\end{array}$ & $\begin{array}{c}11 \\
18 \%\end{array}$ & $\begin{array}{c}36 \\
58 \%\end{array}$ & $\begin{array}{c}10 \\
16 \%\end{array}$ \\
\hline & $\begin{array}{l}\text {... prefer to work with different } \\
\text { partners on each project to maintain } \\
\text { my independence. }\end{array}$ & $\begin{array}{c}2 \\
3 \%\end{array}$ & $\begin{array}{c}15 \\
24 \%\end{array}$ & $\begin{array}{c}20 \\
32 \%\end{array}$ & $\begin{array}{c}20 \\
32 \%\end{array}$ & $\begin{array}{c}5 \\
8 \%\end{array}$ \\
\hline \multirow[t]{2}{*}{ institutional } & $\begin{array}{l}\text {...I find it easier to work with firms } \\
\text { that share my ways of working, } \\
\text { research culture and values. }\end{array}$ & $\begin{array}{l}0 \\
-\end{array}$ & $\begin{array}{c}6 \\
10 \%\end{array}$ & $\begin{array}{c}10 \\
16 \%\end{array}$ & $\begin{array}{c}36 \\
58 \%\end{array}$ & $\begin{array}{c}10 \\
16 \%\end{array}$ \\
\hline & $\begin{array}{l}\text {... w will work with any industrial } \\
\text { partner if it leads to quality } \\
\text { publications or patents. }\end{array}$ & $\begin{array}{c}4 \\
6 \%\end{array}$ & $\begin{array}{c}18 \\
29 \%\end{array}$ & $\begin{array}{c}8 \\
13 \%\end{array}$ & $\begin{array}{c}26 \\
42 \%\end{array}$ & $\begin{array}{c}6 \\
10 \%\end{array}$ \\
\hline \multirow[t]{2}{*}{ geographical } & $\begin{array}{l}\text {...working with local firms helps me } \\
\text { to organize and coordinate my } \\
\text { innovative projects more effectively. }\end{array}$ & $\begin{array}{c}2 \\
3 \%\end{array}$ & $\begin{array}{c}9 \\
15 \%\end{array}$ & $\begin{array}{c}31 \\
50 \%\end{array}$ & $\begin{array}{c}19 \\
31 \%\end{array}$ & $\begin{array}{c}1 \\
2 \%\end{array}$ \\
\hline & $\begin{array}{l}\text {...I will work with local firms only to } \\
\text { acquire high-quality research grants. }\end{array}$ & $\begin{array}{c}17 \\
27 \%\end{array}$ & $\begin{array}{c}22 \\
35 \%\end{array}$ & $\begin{array}{c}16 \\
26 \%\end{array}$ & $\begin{array}{c}7 \\
11 \%\end{array}$ & $\begin{array}{l}0 \\
-\end{array}$ \\
\hline
\end{tabular}

The pattern of location of external partner influenced by five dimensions of proximity demonstrates strong dependence between proximity and location of external partners. In other words, academics agree to cooperate with an external partner located in any area if the cooperation is supported by a high level of proximity. Furthermore, it is worth mentioning which dimension of proximity is the most important for different location of external partners. Firstly, for external parties, academics consider social proximity as the most important dimension of proximity. Secondly, academics chose institutional proximity as the most significant in cooperation with national external partners. Thirdly, cognitive and social proximity is equally important in cooperation 
with European partners. Finally, institutional proximity was primarily important for interaction with global external partners (Table 2).

Table 2. Location of external partner vs proximity ratings (average)

\begin{tabular}{c|c|c|c|c|c}
\hline $\begin{array}{c}\text { Proximity } \\
\text { Location }\end{array}$ & Cognitive & Organization & Social & Institutional & Geographical \\
\hline Local & 3.8 & 3.3 & $\mathbf{4 . 3}$ & 3.7 & 3.5 \\
\hline National & 3.5 & 3.3 & 3.8 & $\mathbf{3 . 9}$ & 3.1 \\
\hline Europe & $\mathbf{3 . 7}$ & 3.1 & $\mathbf{3 . 7}$ & 3.5 & 3.4 \\
\hline Global & 3.3 & 3.4 & 3.5 & $\mathbf{3 . 9}$ & 2.7 \\
\hline Average & 3.6 & 3.3 & 3.8 & 3.8 & 3.2
\end{tabular}

\section{Knowledge Park Twente - 'seedbed' of regional innovation?}

It is notable that localised knowledge communities appear to be more engaged with partners and the national and international levels than the regional; we interpret this as being a consequence of the relatively limited involvement of local businesses in the local knowledge community, with a number of honourable and high profile exceptions. Our findings showed that academics are co-operating with external partners rather actively. Although both researchers and entrepreneurs are interested in collaboration, there are certain blocking factors influencing the UI connectivity that have been described in the earlier sections. The location of external partners is important for researchers in the sense of proximity of interaction. Therefore, academics co-operate with both local and distant partners if the interaction is supported by proximity. Box 2 provides a list of the most salient points emerging from this research as the basis for addressing the questions asked in section 2 and providing insights into this paper's main research question, namely how can KCPs and their underlying shared knowledge resources contribute to participating academics' needs to be excellent in wider academic/ scholarly networks. 
Box 2. Summary of facts: interaction of academics with external partners at the Knowledge Park Twente

- In any type of UI collaborative activities most academics prefer to cooperate with external partners located in national (beyond Twente region) area;

- The $31 \%$ (62 researchers) of all participants (199 researchers) consider themselves as actively involved in co-operation with external partners;

- Collaborative research and problem solving activities are the predominant types of university-external partner relationships;

- The most preferred form of contact in each activity is face-to-face meetings on academic'/external partner' premises

- The most important motivation for academics to cooperate with external partners is developing future research opportunities and maintaining useful contacts;

- The most important facilitators for interaction with external partners despite of the constraints, is cognitive, organisational and social proximity, what means the co-operation with reliable partners and those, which have shared culture and values.

Our first question related to what academics nationally located within KCPs sought to achieve through their engagement with external partners. Our findings were unambiguous in this area - external engagement was primarily related to the business of research activities, secondarily to making their research useful in applications and for society in general, and finally, as part of carrying out excellent research. Our second question related to what types of proximity could influence KCP academic's choices to co-operate with local and distant external partners. In Kennispark, the most important kinds of proximity for external engagement were cognitive, organizational and social proximity. Academics co-operate with external partners - regardless of their location if the cooperation based on a high level of interaction proximity. Geographical proximity is not the most important factor for effective UI partnership. Yet interestingly, results show that regardless of the researchers' background, research experience, type of activity, frequency of cooperation or form of contact they will work with distant external partners as long as that supports high quality research. Our third question was how KCPs could build useful proximity. Our results show that KCP actors are engaged in 
social learning processes to support excellent research underpinned by various forms of proximity. The success of Kennispark suggests that it is not just physical - geographical - proximity that is a result of Kennispark but that they are developing other forms of proximity, cognitive, organisational and social.

The results achieved in this study contribute to the extensive theoretical discussion on knowledge transfer and the role played by specific knowledge transfer spaces technopoles - in knowledge-based urban development. As the literature review shows an empirical gap in quantitative analysis of academics' choices in cooperation with industry, this study contributes to the quantitative analysis research on UI partnership. What was examined in this study appropriately represented the attitude of academics towards partnership with business. It confirmed and idea that social, organisational, strategic and institutional proximity can contribute to the development of an effective network between local and external actors. Therefore, this study proved that geographical proximity is not a prerequisite for effective relationships between university and industry (Ratinho \& Henriques, 2010) but nevertheless the KCP does appear to be building particular kinds of proximity.

To further explore this, we highlight three key stylised facts emerging from our research. Firstly, academics are engaged in knowledge exchange with users (collaborative research and problem solving), secondly that that research is carried out underpinned by social learning processes (face-to-face meetings vs remote contacts) and thirdly that there is a degree of proximity of these external agents with academics. We therefore feel that it is reasonable on this basis to argue that something about Kennispark is contributing to developing those kinds of proximity rather than the effects being entirely ascribable to physical co-location. And critically, to our mind, this is something that neither analyses of Kennispark in particular or studies of KCPs in general have addressed, namely whether place-specific activities are in fact contributing to building other kinds of proximity, cognitive, organisational and social. Clearly, if academics and external users are working together on a piece of research or via a student placement, then this interaction generates shared languages, routines, expectations and understandings that provide cognitive and social proximity. We further contend that this issue - how place specific knowledge sites develop non-place specific proximities requires further analysis. 
This is a piece of exploratory research seeking to understand how the nature of physical knowledge production locations are changing in the context of the social knowledge economy. Therefore we must necessarily be modest in the wider claims that we make but at the same time the idea that knowledge production is localised is coming under criticism. Our argument is that KCPs contribute to forming proximity between academics and users, but that other kinds of proximity may be more important than the purely geographical. We can make an educated guess as to how the interactions between academics and external users build proximities, but it is much harder to discern precisely what the role of the KCPs are in building these shared knowledge bases, repertoires, norms and collective understandings as the basis for effective collaboration. This would represent the obverse of Boekel \& Boschma's (2012) 'proximity paradox' - that despite knowledge exchange being able to take place anywhere, locality remains in some way important in building those proximities between academics and external users. We conclude in contending that if technopoles are to retain their salience as a 21st century spatial form then it will be as much because of their promotion of non-spatial as spatial forms of proximity, a situation that would demand much further reflection and consideration from the field.

For policy-makers, there are also clear implications, in seeking to improve the openness of the knowledge community to local partners and to increase their benefits from the KCP in order to stimulate "Cambridge effect" style benefits. Success or failure in the regional engagement of KCPs has serious implications for the regions in terms of increasing their smart specialization in innovation based economic development. There is already a good understanding of how to encourage firms to improve their innovation performance, taking them along an innovation journey through raising their awareness of the value of innovation. This typically involves introducing them to those in similar situations and/ or able to help them, and to take the first steps in innovative investments with innovation vouchers, proof-of-concept funds and ultimately venture capital. We argue that policy-makers, investing substantially in these new-style technopoles such as Kennispark, might also seek to use small innovation investments to encourage local firms outwith the KCP nor only to innovate, but to participate more actively in the life of the knowledge community, and maximise the benefits they bring to their regions and nations. 


\section{Acknowledgements}

The authors would like to acknowledge the contributions of the respondents to our survey who gave their time to provide us with research data. We also acknowledge the assistance of the secretariats of the university research institutes in helping us to identify the research-active staff in the university that formed the basis for the population for the survey. Any errors or omissions remain the responsibility of the authors. 


\section{Bibliography}

Amin, A. and Roberts, J. (2008) 'Knowing in Action: Beyond Communities of Practice', Research Policy, 37 (2), 353-369.

Anttiroiko, A. V. (2004) Science cities: their characteristics and future challenges. International Journal of Technology Management, 28(3), 395-418.

Asheim, B. T., Boschma, R., \& Cooke, P. (2011) Constructing regional advantage: platform policies based on related variety and differentiated knowledge bases. Regional Studies, 45(7), 893904.

Baldini, N., Grimaldi, R., Sobrero, M. (2007) To patent or not to patent? A survey of Italian inventors on motivations, incentives, and obstacles to university patenting. Scientometrics 70, 333-354.

Benneworth, P. S. and Charles, D. R. (2005) “University spin off companies and the territorial knowledge pool: building regional innovation competencies?" European Planning Studies, 13 (4) pp. 537-557.

Benneworth, P. S. and Hospers, G. J. (2007) "Urban competitiveness in the knowledge economy: universities as new planning animateurs” Progress in Planning 23 (1) pp. 3-102.

Benneworth, P. S. and Ratinho, T. (2014a) "Reframing the role of knowledge parks and science cities in knowledge based urban development" Environment \& Planning C (forthcoming).

P. Benneworth and Ratinho, T. (2014b) Regional innovation culture in the social knowledge economy" in R. Rutten, P. Benneworth, D. Irawati \& F. Boekema (eds) The social dynamics of innovation networks London, Routledge.

Benneworth, P. , Hospers, G. J., Jongbloed, B., Leiyste, L. and Zomer, A.. (2011) "The 'science city' as a system coupler in fragmented strategic urban environments?", Built Environment, 37 (3) pp. 317-335.

Benneworth, P. S., Hospers, G. J. and Timmerman, P. (2009) "Who builds "science cities" and "knowledge parks"? High technology firms mobilising heterogeneous commercialisation networks" in R. Oakey, S. Kauser, A. Groen and P v.d. Sijde (eds.) New technology based firms in the new millennium Vol 7, London: Elsevier, forthcoming.

Bøås, M. and McNeill, D.(2004) Ideas and Institutions: Who is Framing What? In M. Bøås \& D. McNeill (eds.). Global Institutions and Development: Framing the World? London: Routledge, pp. 1-12.

Böhme, K. and Gløersen, E. (2011). Territorial cohesion storylines: Understanding a policy concept.

Boschma, R. A. (2005) "Proximity and Innovation: A Critical Assessment”, Regional Studies, 39(1), pp. 61-74.

Broekel, T. and Boschma, R. (2012) Knowledge networks in the Dutch aviation industry: the proximity paradox. Journal of Economic Geography 12 (2), 409-433. 
Caniëls M. C.J., Kronenberg, K. and Werker, C. (2014) “Conceptualizing Proximity in Research Collaborations" in R. Rutten, P. Benneworth, D. Irawati \& F. Boekema (eds) The social dynamics of innovation networks London, Routledge.

Castells, M and Hall, P. (1994) Technopoles of the world: the making of 21st century industrial complexes, London: Routledge.

Charles, D.R. and Wray, F. (2010) 'Science cities in the UK', Melbourne 2010 Knowledge Cities World Summit, Melbourne, 16th-19th November.

Clark, B. (1998) "The Entrepreneurial University: Demand and Response”. Tertiary Education and Management, Vol.4, No.1, 5-16.

Cooke, P (2005) Regionally asymmetric knowledge capabilities and open innovation : exploring 'Globalisation 2' - a new model of industry organisation, Research Policy, 34, pp. 11281149.

D'Este, P.and Perkmann, M. (2011) Why do academics engage with industry? The entrepreneurial university and individual motivations. Journal of Technology Transfer 36, 316-339.

Freitas, I.M.B., and B. Verspagen (2009) The motivations, organization and outcomes of university-industry", Available at: http://www.socialsciences.leiden.edu/cwts/news/scoreboard.html.

Garud, R. (1997) “On the distrnction between know-how, know-why and know-what”, Advances in Strategic Management Vol. 14, p. 81-101.

Gertler, M. (1995) “"Being there”: proximity, organisation and culture in the development and adoption of advanced manufacturing technologies', Economic Geography 71 (1) pp 126.

Gertner, D., Joanne Roberts, David Charles, (2011) "University-industry collaboration: a CoPs approach to KTPs", Journal of Knowledge Management, Vol. 15 Iss: 4 pp. 625 - 647.

Gordon, I. R. and McCann, P. (2005) "Innovation, agglomeration, and regional development", Journal of Economic Geography 5 (5): 523-543.

Hospers, Gert-Jan (2006) "Silicon Somewhere? Assessing the usefulness of best practices in regional policy." Policy studies 27.1: 1-15.

Kerngroep Innovatie (2012) Innovatiesprong Twente: Naar meer inhoudelijke focus en vernieuwing van de aanpak. Hoofdlijn van de strategie voor het innovatiebeleid en de governance voor de periode 2012-2015, Available at: http://ris.enschede.nl/stukken/09638/download.html

Korotka, M. A. (2012) Proximity factors influencing academics' decisions to co-operate with industry - a case study of the University of Twente's research institutes, Unpublished M. Sc. Thesis Available at: http://purl.utwente.nl/essays/62013/ (Last accessed 8th April 2012).

Knight, R. V. (1995) Knowledge-based development: policy and planning implications for cities. Urban Studies, 32(2), 225-260. 
Lam, A. (2010) What motivates academic scientists to engage in research commercialization: 'Gold','ribbon' or 'puzzle'? Research policy 40, 1354-1368.

Lazaretti, L. \& E. Tavoletti (2007) "Higher Education Excellence and Local Economic Development: The Case of the Entrepreneurial University of Twente", European Planning Studies, 13:3, pp. 475-493

McCann, P. \& Ortega-Argilés, R. (2013) "Modern regional innovation policy." Cambridge Journal of Regions, Economy and Society 6.2 187-216.

Martin, R. and Sunley, P. (2003) "Deconstructing clusters: chaotic concept or policy panacea?" Journal of Economic Geography 3 (1) pp 5-35. May, T. \& Perry, B. (2011) "Urban research in the knowledge economy: context, content and outlook" Built Environment 37 (3), pp. 352267.

Miller, S. (2014) “The Strathclyde Technology and Innovation Centre in Scotland's Innovation System" Regional Studies, Regional Science (forthcoming)

May, T. and Perry, B. (2010)

Nonaka, I. \& Takeuchi, H. (1995) The knowledge creating company: how Japanese companies create the dynamics of innovation, New York: Oxford University Press.

OECD (2011). "Regions and Innovation Policy", OECD Reviews of Regional Innovation, OECD Publishing, pp. 25-84 (available at: http://www.oecd.org/document/2/0,3746,en_2649_37429_47721730_1_1_1_37429,00.ht $\mathrm{ml}$ )

Perry, B. and May, T. (2010a) "Urban knowledge exchange: devilish dichotomoies and active intermediation" International Journal of Knowledge-based Development 1(1/2), pp. 6-24.

Perry, B. and May, T. (2011) "Urban research in the knowledge economy: content. Context and Outlook”. Built Environment. Vol 37 (3). pp. 352-367.

Ratinho, T., and Henriques, E. (2010) "The role of science parks and business incubators in converging countries: Evidence from Portugal." Technovation, 30(4), 278-290.

Ratinho, T. (2011) Are they helping? An examination of business incubators' impact on tenant firms. Unpublished PhD Thesis Available at: http://doc.utwente.nl/78235/1/thesis_T_Ratinho.pdf

Romer, P. M. (1994) “The origins of endogenous growth" Journal of Economic Perspectives 8 (1) pp 322.

Schutte, F. (1999) "The University-Industry Relations of an Entrepreneurial University: The Case of the University of Twente". Higher Education in Europe, 24:1, 47-65.

Quintas, P., Wield, D., \& Massey, D. (1992) Academic-industry links and innovation: questioning the science park model. Technovation, 12(3), 161-175.

Smith, R. G. (2003) “World city actor networks” Progress in Human Geography 27 (1) pp 2544. 
Solow, R. (1994) "Perspectives on growth theory" Journal of Economic Perspectives 8 (1) pp 45 54.

Temple, J. (1998) "The new growth evidence” Journal of Economic Literature, 37 (1) pp. 112156.

Yeung, H. W. (2009) "Situating regional development in the competitive dynamics of global production networks: an East Asian perspective" in H. W. Yeung (ed) Globalizing regional development in East Asia: production networks, clusters, and entrepreneurship, London: Routledge.

Yigitcanlar, T., and Velibeyoglu, K. (2008) "Knowledge-Based Urban Development: The Local Economic Development Path of Brisbane, Australia." Local Economy, 23(3), 195-207.

Yigitcanlar, T. (2010) "Making Space and Place for the Knowledge Economy: Knowledge-based Development of Australian Cities." European Planning Studies, 18 (11) pp. 1769-1786 
The Center for Higher Education Policy Studies (CHEPS) is a research institute (WHW, Article 9.20) located in the Faculty of Behavioural and Management Sciences within the University of Twente, a public university established by the Dutch government in 1961. CHEPS is a specialized higher education policy centre that combines basic and applied research with education, training and consultancy activities. 